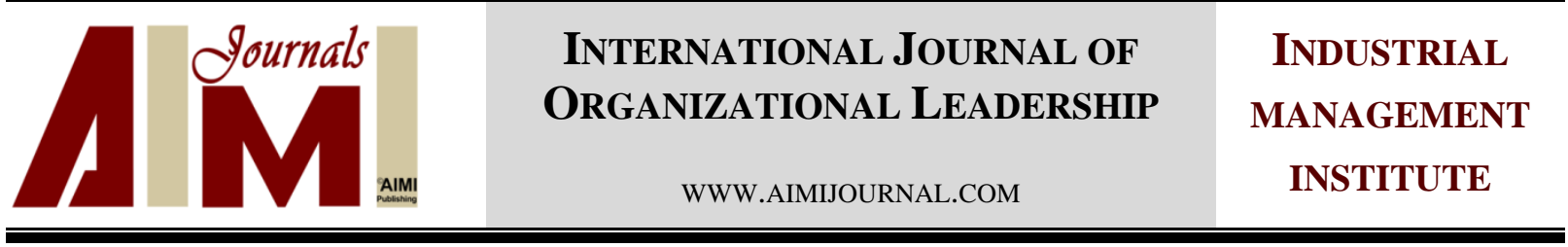

\title{
Examining the role of information and communication technology in the organizational structure of the QaemShahr municipality
}

\author{
Alireza Dadashi Jokandan ${ }^{1 *}$, Majid Fattahi ${ }^{2}$, Seyyedeh Fatemeh Ghane ${ }^{3}$ \\ 1,2Department of Management, Sari Branch, Islamic Azad University, Sari, Iran \\ ${ }^{3}$ Department of Management, Chalus Branch, Islamic Azad University, Chalus, Iran
}

\begin{abstract}
Keywords:

ICT, Complexity,

Formality, Centralization

Correspondence:

phdalirezadadashi@yahoo.com

In the era of progress and technology development, organizations in order to accelerate the delivery of services, reduce costs, and gain customer satisfaction seek to fulfill these goals through the development of information technology and appropriate organizational structure and QaemShahr municipality is not an exception. In this study, the organizational structure is the combination of the complexity, formality, and centralization and the ICT as a part of an organizational system that is impressive in the effectiveness of the activities is taken into consideration. This study is an applied research adopting a descriptive method. Following this, 100 people from QaemShahr municipality were participated in the study of whom 80 staff were elected as the sample size. To collect the data for examining the relationship between ICT and organizational structure, a researcher-made questionnaire with 0.86 Cronbach's alpha coefficient and Stephen Robins standard questionnaire to assess the organizational structure were used. To analyze the data, SPSS software was used for inferential statistics. The results indicated that ICT had impact on organizational structure and among the three dimensions of the structure, formality had the highest level of significance with ICT. There is no significant difference in awareness of ICT among women and men as well as the impact of ICT on the organizational structure at different levels in QaemShahr municipality.
\end{abstract}

(C)AIMI Journals

The rapid development of superior technology has influenced all aspects of human life and organizations are not the exception. Organizations that act in the business area solely based on organizational evident advantages such as machinery and equipment cannot achieve a competitive advantage in a knowledge-based economy while organizations active in the 
information age and knowledge-based economies should focus on new intangible resources and organizational capabilities such as knowledge and skills, strategy, innovation, processes and systems and organizational structure, organizational culture, good relationship with colleagues and suppliers, and better control of supply and distribution networks as factors in gaining competitive advantage.

For instance, most enterprises in different countries use the traditional methods of financial accounting that centuries ago they were created for a business environment based on manual work and tangible assets such as equipment and buildings while knowledge-based business environment requires new organizational model that include new intangible organizational assets such as knowledge and competence of human resources, innovation, relationship with customers, organizational culture, systems and processes, and organizational structure.

About two decades ago, ICT was developed as an interdisciplinary expertise and then by creating telecommunications, it was used to access the information and prevent the accumulation of information. Impact of ICT on management tasks is increasingly expanding. This technology like any other technology can be studied from different aspects, but there are some aspects of it that due to the increased usage in various organizations has gained a special place.

Experts have classified these applications into two categories: First, the application operations which refer to the use of information technology in a particular specialty; secondly, the application of ICT that facilitates information collection, storage, and dissemination of the information.

The organizational structure is the combination of the complexity, formality, and centralization which refers to the number of different jobs within an organization, levels and hierarchies within the organization, the usage level of rules and regulations, jurisdiction, and the level of centralization in decision-making. Based on previous research, IT clearly has an impact on all aspects of the organization and has evolved it. In this case, the organization's administrators are responsible that besides the gaining of scientific competences try to have broad and deep understanding of ICT functions in order to be able to implement necessary strategies to identify ICT dimensions, have a clear understanding of the barriers to adoption of these technologies, and apply it to carry out its tasks (Abbasnejad, 2014).

In urban management structure, since mission or philosophy of municipalities as a social institution is providing security for citizens and proper service delivery, it is considered as a serving organization for citizens and people are at the top of the organizational pyramid in urban service centers. Urban management should focus on the satisfaction of their citizens. This idea was born out of sophisticated, advanced, and developed look that a number of factors including new developments, virtual and structural dependency, communication within and outside the organization, and the development of transactions spaces force the urban management to create a new form and technique, appropriate and consistent with these developments. To this end, in the current study, ICT and organizational structure are studied which are considered as two major factors affecting the efficiency and effectiveness of the organization and have a significant effect on the development of the organization and its services, job satisfaction of employees, and providing better services to the organizations. 
The main objectives of the study are examining the role of ICT in organizational structure in QaemShahr municipality and providing guidelines and suggestions for reducing barriers of ICT implementation in QaemShahr municipality. Following this, the secondary objectives involve checking the status of information technology with each of the dimensions of the structure, examining the status of information technology on male and female employees, and investigating the status of organizational levels with ICT.

To acquire this insight, we call three of the most essential classic organizational structure dimensions, namely centralization, formalization, and specialization and estmate their impact on ICT. These classic organizational structure dimensions include supporting the differentiation-integration balance that has been the main focus in the classic organization theory literature (Lawrence \& Lorsch, 1969; Miller \& Droge, 1986; Mintzberg, 1979). Centralization and formalization refer to tuning and integrating units' tasks and behavior, while specialization indicates causing differentiation among units. Although classic, these aspects are still generally used in organizational design research (Cunningham \& Rivera, 2001; Tsai, 2002). Three of these aspects have also been used in the late study of Chen and Huang (2007).

\section{The Literature Review}

ICT is the use of computers and other technologies to deal with information. Following this, ICT is considered as a tool for storing, processing, and presentation of information that is used electronically and is based on a number of media and is utilized in various forms (Baghban et al., 2012). According to Mardi (2015), the definitions of ICT can be classified from three perspectives, namely classic definition, technical definition, and the general definitions of ICT.

The classic definition refers to collecting, organizing, storing, sending, and publishing data such as audio, video, text, or numbers that can be done using computer and telecommunication tools (Mintzberg, 1979).

The technical definition refers to ITC is the equipments and methods are needed to convert text, audio, video, and film to storage and retrieval digital Information.

In general, definitions of ICT, all forms of communication and technology that are used to create, store, send and use various forms of information including commercial data, voice conversations, animated images, and multimedia data came into use (Abbasnejad, 2014).

In recent years, we face the unprecedented deployment of ICT in the world and in developing countries, these technologies have been used for different development projects. Following this, ICT has been introduced as the main axis of the development in the world and is considered as the fundamental part of growth and economic development.

Identifying the position of ICT applications is of great importance. These positions are divided into two categories, namely the positions outside the organization and positions within the organization. The positions outside the organization implies that the usage of technology leads to the improvement of organization's activities in relation with customers, development of the affiliated companies that provides service, and offering new products or services to customers. Following this, in the positions within the organization, using technology causes the increment of the quality of the stored value in various parts from including production line, human resources management of financial and service sectors (Baghban et al., 2012).

The results of country studies and studies abroad are summarized in Table 1. 
Table 1

The Results of the Country Studies and Studies Abroad

\begin{tabular}{|c|c|c|}
\hline Researchers & $\begin{array}{l}\text { Year of } \\
\text { study }\end{array}$ & Research Description \\
\hline $\begin{array}{l}\text { Farhangi, } \\
\text { Abbaspoor, and } \\
\text { Abbasian Ghasemi }\end{array}$ & 2013 & $\begin{array}{l}\text { They examined the impact of organizational structure and performance of the consulting engineering } \\
\text { companies. The results showed that ICT has affected organizational structure and performance of } \\
\text { consulting companies. }\end{array}$ \\
\hline $\begin{array}{l}\text { Azizi, } \\
\text { Mehrabi Koushki, } \\
\text { and Jalali Farahani }\end{array}$ & 2012 & $\begin{array}{l}\text { They investigated the relationship between the information technology and organizational structure of the } \\
\text { Ministry of Sport and Youth. The findings revealed that the use of information technology in the Ministry } \\
\text { of Youth and Sports is correlated with the organizational structure and information technology affected the } \\
\text { organizational structure (complexity, formality, and centralization) with different intensity and size. }\end{array}$ \\
\hline $\begin{array}{l}\text { Baghban, } \\
\text { Hallaj Dehghani, } \\
\text { and Moghyan }\end{array}$ & 2012 & $\begin{array}{l}\text { In this study, the relationship between information technology and organizational structure are examined } \\
\text { such as complexity, formality, and centralization in Islamic Azad University, Buin Zahra Branch. The } \\
\text { results showed that the use of information technology affected all three components of the organizational } \\
\text { structure. }\end{array}$ \\
\hline Willem and Buelens & 2009 & $\begin{array}{l}\text { They study how classic organizational structure dimensions should be altered to be more adapted to } \\
\text { organizational knowledge sharing. In particular, they look at the dimensions: coordination, centralization, } \\
\text { formalization, and specialization, in their relationship to the concept of knowledge sharing. Their findings } \\
\text { indicated that expected relationships, such as the negative effect of centralization or the positive effect of } \\
\text { lower formalization, were not found. Interdependency and knowledge complexity, caused by } \\
\text { specialization, had an important interacting effect on the relationship between coordination and knowledge } \\
\text { sharing. A comparison between the two companies revealed that the organization-specific context in which } \\
\text { the coordination is applied influences the potential of this coordination for knowledge sharing. }\end{array}$ \\
\hline
\end{tabular}

\section{Conceptual Model}

Figure 1 shows the conceptual model of research.

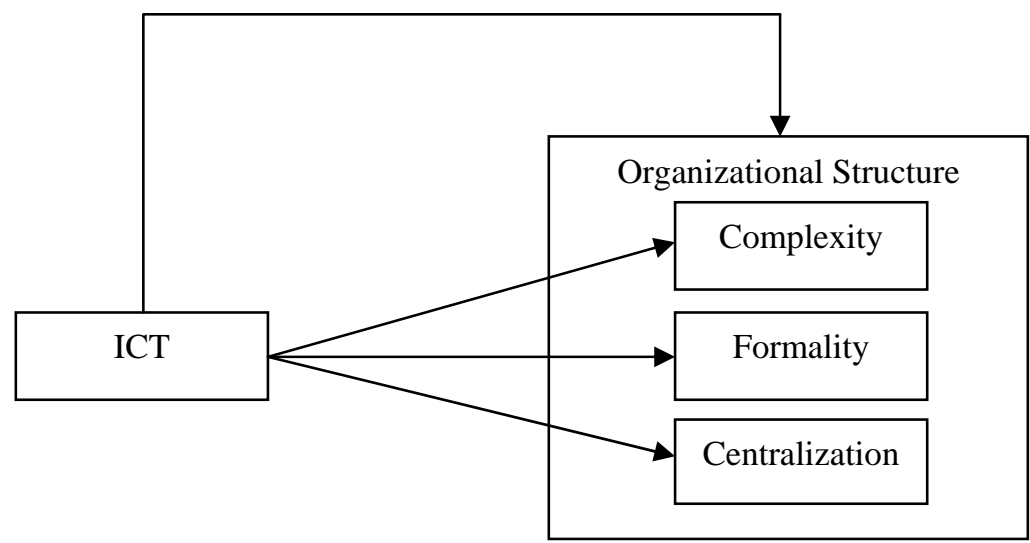

Figure 1. Conceptual model of research

\section{Variables}

In the present study, organizational structure and ICT have been considered as an independent variable and a dependent variable, respectively.

ICT: The operational definition of this variable refers to the managers' use of tools, equipment, methods, and applications of knowledge and also, using the necessary skills for accessing, production, storage, processing and transmission of information or performing administrative tasks using computer equipment telecommunications such as telephone, internet, and intranet that are used for organizational affairs.

\section{Organizational Structure}


Daft (2010) states that the organizational structure appears in the organizational chart. Following this, organizational chart is a visible symbol of the whole process and activities of the organization.

Complexity: In this section, there exist three kinds of separation including vertical separation, horizontal separation, and spatial or geographical separation.

Vertical separation refers to the depth or height of the organizational structure. As the levels increase, the organizational hierarchy increases as well and it leads to the complexity of the organization.

Following this, horizontal separation implies that having different and wider variety of jobs in the organization requires certain skills and knowledge and regarding vertical separation, the organization tends to be more complicated. The most important evidence that suggests horizontal separation within the organization is the specialization and division within the organization. Horizontal and vertical separation should not be considered as two entirely separate categories. Vertical separation may be an appropriate response for increasing horizontal separation in the organization.

The third element that complexity of the organization stems from it refers to spatial or geographical separation. The separation is performed based on geographical regions and it shows the the distribution of offices, factories, and people of the organization according to geographical regions. Geographical distribution refers to the distance that exists among the units, organizations, and staffs. The more the geographical distribution, the more its complexity would be.

Hage (1980) introduced the characteristics of organizational structure and mentioned that the degree of these characteristics are different in various organizations. This contributed to a long pace on the route of investigation of organization format. Complexity means the number of tasks or sub-systems in an organization (Shafiee, Razminia, \& Zeymaran, 2016).

Formality: Formality mentions the standard level of organizational jobs. In a formal organization, organizational relations are described for employees in written form and regarding the organizational chart and, if necessary, the following changes are introduced by manger formally; but considering the informal organization, organizational relations are demonstrated verbally for employees, and if necessary, are revised naturally (Shafiee et al., 2016).

Formalization reveals the extent to which the rights and responsibilities of the members of the organization are regulated and the extent to which these are presented in the form of rules, procedures, and instructions (Schminke, Ambrose, \& Cropanzano, 2000).

Centralization: Hage (1980) explain centralization in line with the contribution of individuals in decision-making. Researchers indicate that those public institutions searching for effective and satisfactory administration of performance must observe the organizational structure and move their attention from centralized systems to non-centralized ones to make possible the higher levels of opinions and votes (Caruana, Ewing, \& Ramaseshan, 2002). The centralization dimension is the determinant of individuals having the right of decision making in organization (Fry, Slocum, \& John, 1984).

\section{Method}


This study is an applied research adopting a descriptive method that aimed to describe the relationship between information technology and organizational structure. Following this, 100 people from QaemShahr municipality were participated in the study of whom 80 staff were elected randomly as the sample size. To collect the data, a researcher-made questionnaire with 0.86 Cronbach's alpha coefficient and Stephen Robins standard questionnaire to assess the organizational structure were used. To analyze the data, SPSS software was used for inferential statistics.

\section{Results}

\section{Main Hypothesis: ICT affects the organizational structure of QaemShahr Municipality.}

$\mathrm{H}_{0}$ : ICT has no effect on the organizational structure.

$\mathrm{H}_{1}$ : ICT affects the organizational structure.

Table 2

Examining T-Test in Main Hypothesis

\begin{tabular}{ccccccc}
\hline Test Level & Sig. & Critical t & Df & T-Value & SD & Mean \\
\hline 0.05 & 0.000 & 1.66 & 79 & 21.029 & 0.381 & 3.89 \\
\hline
\end{tabular}

According to Table 2, as calculated $t$-value is greater than critical t (1.66) with 79 percent of degree of freedom (df) and significance level of 0.05 and since significance level is less than test level, so $\mathrm{H}_{0}$ is not confirmed and majority of the respondents agree that IT affects organizational structure.

\section{Secondary Hypotheses:}

$H_{1}$ : IT affects the complexity of the organization.

$\mathrm{H}_{0 \mathrm{a}}$ : ITC has no effect on the complexity of the organization.

$\mathrm{H}_{1 \mathrm{a}}$ : ITC affects the complexity of the organization.

Table 3

Examining T-Test in the First Secondary Hypothesis

\begin{tabular}{ccccccc}
\hline Test Level & Sig. & Critical t & df & T-Value & SD & Mean \\
\hline 0.05 & 0.000 & 1.66 & 79 & 10.457 & 0.700 & 3.81 \\
\hline
\end{tabular}

Regarding Table 3, as calculated $t$-value is greater than critical t (1.66) with 79 percent of degree of freedom (df) and significance level of 0.05 and since the significance level is less than test level, so $\mathrm{H}_{0 \mathrm{a}}$ is not confirmed and majority of the respondents agree that there was a significant relationship between the effect of IT and the level of complexity.

\section{$\mathrm{H}_{2}$ : IT affects the formality of the organization.}

$\mathrm{H}_{0 \mathrm{~b}}$ : IT has no effect on the formality of the organization.

$\mathrm{H}_{1 \mathrm{~b}}$ : IT affects the formality of the organization.

Table 4

Examining T-Test in Second Secondary Hypothesis

\begin{tabular}{ccccccc}
\hline Test Level & Sig. & Critical t & df & T-Value & SD & Mean \\
\hline 0.05 & 0.000 & 1.66 & 79 & 18.19 & 0.540 & 4.10 \\
\hline
\end{tabular}


According to Table 4, as calculated t-value is greater than critical t (1.66) with 79 percent of degree of freedom (df) and significance level of 0.05 and because the significance level is less than test level, to this end, $\mathrm{H}_{0 \mathrm{~b}}$ is not confirmed and majority of the respondents agree that the impact of IT on organizational formality is significant.

\section{$\mathrm{H}_{3}$ : IT affects the centralization of the organization.}

$\mathrm{H}_{0 \mathrm{c}}$ : ITC does not affect the centralization of the organization.

$\mathrm{H}_{1 \mathrm{c}}$ : ITC affects the centralization of the organization.

Table 5

Examining T-Test in Third Secondary Hypothesis

\begin{tabular}{ccccccc}
\hline Test Level & Sig. & Critical t & df & T-Value & SD & Mean \\
\hline 0.05 & 0.000 & 1.66 & 79 & 10.102 & 0.682 & 3.77
\end{tabular}

As Table 5 shows, the calculated t-value is greater than critical t (1.66) with 79 percent of degree of freedom (df) and significance level of 0.05 and since test level is less than significance level, $\mathrm{H}_{0 \mathrm{c}}$ is not confirmed and majority of the respondents agree that IT impacts organizational centralization.

\section{$\mathrm{H}_{4}$ : IT has different effects on each of the organizational structure components.}

Table 6

Comparing the Effect of Applying IT in Organizational Structures

\begin{tabular}{ll}
\hline Variable & Mean \\
\hline The Impact of ICT on Complexity & 3.81 \\
The Impact of ICT on Formality & 4.1 \\
The Impact of ICT on Centralization & 3.77 \\
\hline
\end{tabular}

According to Table 6, by comparing the mean scores of each of the variables regarding limited questions, it becomes clear that the highest mean scores of the respondents refer to the relationship of ICT with formality, complexity, and centralization, respectively. Thus, it could be stated that ICT probably has the greatest impact on the formalization of the municipality of Qaemshahr.

\section{$\mathrm{H}_{5}$ : The impact of IT is different among the male and female employees.}

$\mathrm{H}_{0 \mathrm{~d}}$ : The impact of information technology on men and women is not different.

$\mathrm{H}_{1 \mathrm{~d}}$ : The impact of information technology on men and women are different.

Table 7

Examining T-Test in Fifth Secondary Hypothesis

\begin{tabular}{llllllll}
\hline Test Level & Sig. & Critical t & df & T-Value & SD & Mean & Group \\
\hline 0.05 & 0.058 & 1.99 & 78 & 1.92 & 0.329 & 3.96 & Men \\
& & & & 0.435 & 3.79 & Women \\
\hline
\end{tabular}


Considering Table 7, as calculated t-values is less than critical t (1.99) with 78 percent of degree of freedom (df) and significance level of 0.05 and since test level is greater than significance level, so $\mathrm{H}_{0 \mathrm{~d}}$ is confirmed and majority of the respondents agree that there is no difference between the impact of ICT among men and women and organizational structure.

\section{$H_{6}$ : IT has a different effect in each of the organizational levels.}

$\mathrm{H}_{0 \mathrm{e}}$ : The impact of information technology at different organizational levels is not different. $\mathrm{H}_{1 \mathrm{e}}$ : The impact of information technology at various levels of the organization is different.

Table 8

Examining ANOVA in Sixth Secondary Hypothesis

\begin{tabular}{lllll}
\hline Test Level & Sig. & Critical F & df & F-Values \\
\hline 0.05 & 0.339 & 2.338 & 5.74 & 1.156 \\
\hline
\end{tabular}

As Table 8 presents, the calculated F-values is less than critical F (2.338) with 5.74 percent of degree of freedom and significance level of 0.05 . Since the significance level is less than test level, so, $\mathrm{H}_{0 \mathrm{e}}$ is confirmed and majority of the respondents agree that there is no significant difference between the impact of ICT on organizational structure at different levels of the organization.

\section{Discussion and Conclusion}

Beneficiaries of this applied study are organizations and individuals including QaemShahr municipality organization, urban management and all its employees, all citizens, and all scholars and students of executive management. The results showed that IT can have an effect on each of the indicators; for example, it can affect geographical breakdown by increasing or decreasing the number of specialists, having unity or eliminating some jobs, creation of special units for horizontal separation by reducing or increasing the scope of supervision and the number of organizational levels in vertical separation, and by providing facilities such as teleconferencing. The findings revealed that ICT had a great impact on the organizational structure and it reduced the complexity of the organization. In some cases, it was observed that despite the increased workload or organizational units, the number of workers did not increase which is the result of the use of ICT in the organization.

In addition, it was concluded that ICT had a huge impact on the formality of the organizations, so that rules and regulations monitor organizational affairs in written form. For instance, about the organizational formality, there exist processes in government agencies that make the employees to feel obliged to observe the laws and regulations. Moreover, the study showed that ICT affected organizational centralization and delegation of authority was partly perceived in the organization.

\section{References}

Abbasnejad, K. M. (2014). Examining the role of information and communication technology in the organizational structure (Unpublished master's thesis). Sari Branch, Islamic Azad University, Sari, Iran.

Azizi, B., Mehrabi Koushki, A., \& Jalali Farahani, M. (2012). Investigate the relationship between the information technology and organizational structure in the ministry of youth affairs and sports in the Islamic Republic of Iran. Journal of Sport Management, 5(3), 161-173. 
Baghban, M., Hallaj Dehghani, A., \& Moghyan, D. (2012). Examining the information technology and organizational structure of Islamic Azad University of Buin Zahra. Journal of Research in Educational Management, 3(4), 15-28.

Barney, J. B., \& Griffin, R. W. (1992). The management of organization: Structure, strategy, and behavior. Boston: Houghton Mifflin Company.

Caruana, A., Ewing, T. M., \& Ramaseshan, B. (2002). Effects of some environmental challenges and centralization on the entrepreneurial orientation and performance of public sector entities, The Service Industries Journal, 22(2), 43-58.

Chen, C. J., \& Huang, J. W. (2007). How organizational climate and structure affect knowledge management: The social interaction perspective. International Journal of Information Management, 27, 104-118.

Cunningham, G. B., \& Rivera, C. A. (2001). Structural designs within American intercollegiate athletic departments. The International Journal of Organizational Analysis, 9, 369-390.

Daft, R. L. (2010). Organization theory and design. Cincinnati, OH: South-Western College.

Farhangi, A. A., Abbaspoor, A., \& Abbasian Ghasemi, R. (2013). Examining the impact of new communication and information technologies on organizational structure and performance of service companies: A case study of consulting engineers and surveyor. Journal of Information Technology Management, 5(3), 123-146.

Fry, L., Slocum, W., \& John, W. (1984). Technology, structure and work group effectiveness: A test of a contingency model. Academy of Management Journal, 27(2), 221-246.

Hage, J. (1980). Theories of organizations. New York: John Willy and Son, Inc.

Hezar Jaribi, J. (2006). Entrepreneurship. Tehran: Institute of Economic Affairs.

Liao, C., Chuang, S. H., \& To, P. L. (2011). How knowledge management mediates the relationship between environment and organizational structure. Journal of Business Research, 64(7), 728-736.

Lawrence, P. R., \& Lorsch, J. W. (1969). Developing organizations: Diagnosis and action. Reading, MA: Addison-Wesley Publishing Company.

Mardi, S. (2015). Role of IT on increasing employees efficiency in NAJA. Development of Human Resources Management \& Support Journal, 1(35), 97-116.

Miller, D. \& Droge, C. (1986). Psychological and traditional determinants of structure. Administrative Science Quarterly, 31, 539-560.

Mintzberg, H. (1979). The structuring of organizations. Englewood Cliffs: Prentice Hall.

Nawabzadeh, A. (2001). ICT methods and its teaching. Tehran: Golsaram.

Robbins, S. P. (1990). Organization theory: Structure, design, and application (3 ${ }^{\text {rd }}$ ed.). Englewood Cliffs, NJ: Prentice Hall, Inc.

Schminke, M., Ambrose, M. L., \& Cropanzano, R. S. (2000). The effect of organizational structure on perceptions of procedural fairness. Journal of Applied Psychology, 85, 294-304.

Shafiee, H., Razminia, E., \& Zeymaran, N. K. (2016). Investigating the relationship between organizational structure factors and personnel performance. International Journal of Management, Accounting \& Economics, 3(2), 160-165.

Tsai, W. (2002). Social structure of competition within a multiunit organization: Coordination, competition, and interorganizational knowledge sharing. Organization Science, 13(2), 179-190.

Willem, A., \& Buelens, M. (2009). Knowledge sharing in inter-unit cooperative episodes: The impact of organizational structure dimensions. International Journal of Information Management, 29(2), 151-160. 